Article

\title{
Antibacterial Activity and Action Mechanism of the Essential Oil from Enteromorpha linza L. against Foodborne Pathogenic Bacteria
}

\author{
Jayanta Kumar Patra ${ }^{1}$ and Kwang-Hyun Baek ${ }^{2, *}$ \\ 1 Research Institute of Biotechnology \& Medical Converged Science, Dongguk University, Ilsandong-gu, \\ Gyeonggi-do 10326, Korea; jkpatra.cet@gmail.com \\ 2 School of Biotechnology, Yeungnam University, Gyeongsan, Gyeongbuk 712-749, Korea \\ * Correspondence: khbaek@ynu.ac.kr; Tel.: +82-53-810-3029; Fax: +82-53-810-4769
}

Academic Editor: Luca Forti

Received: 12 February 2016 ; Accepted: 17 March 2016 ; Published: 21 March 2016

\begin{abstract}
Foodborne illness and disease caused by foodborne pathogenic bacteria is continuing to increase day by day and it has become an important topic of concern among various food industries. Many types of synthetic antibacterial agents have been used in food processing and food preservation; however, they are not safe and have resulted in various health-related issues. Therefore, in the present study, essential oil from an edible seaweed, Enteromorpha linza (AEO), was evaluated for its antibacterial activity against foodborne pathogens, along with the mechanism of its antibacterial action. AEO at $25 \mathrm{mg} /$ disc was highly active against Bacillus cereus (12.3-12.7 mm inhibition zone) and Staphylococcus aureus (12.7-13.3 mm inhibition zone). The minimum inhibitory concentration and minimum bactericidal concentration values of AEO ranged from $12.5-25 \mathrm{mg} / \mathrm{mL}$. Further investigation of the mechanism of action of AEO revealed its strong impairing effect on the viability of bacterial cells and membrane permeability, as indicated by a significant increase in leakage of $260 \mathrm{~nm}$ absorbing materials and $\mathrm{K}^{+}$ions from the cell membrane and loss of high salt tolerance. Taken together, these data suggest that $\mathrm{AEO}$ has the potential for use as an effective antibacterial agent that functions by impairing cell membrane permeability via morphological alternations, resulting in cellular lysis and cell death.
\end{abstract}

Keywords: antibacterial property; Bacillus cereus; Enteromorpha linza; essential oil; seaweed; Staphylococcus aureus

\section{Introduction}

Reports on foodborne illness and disease caused by consumption of food contaminated by foodborne pathogens are increasing day by day throughout the world [1,2]. Food spoilage, food poisoning and other food-related diseases have become an important topic of concern among various food industries [3,4]. Different synthetic additives and antimicrobial agents are continuously used during the processing of food to avoid contamination and increase of shelf-life by diminishing the growth of microorganisms [5]. However, there is increasing consumer concern regarding the safety of the synthetic chemicals used to preserve foods and their side effects. Much attention is being given throughout the world to minimize the use of synthetic antibacterial agents in food processing and food preservation. Therefore, there has been increasing interest in identifying natural and safe antibacterial compounds from various natural sources.

Plant-based essential oils have been widely applied for a variety of purposes for thousands of years [6,7]. Essential oils or volatile oils extracted from plants are aromatic oily liquids composed of a mixture of phenolic compounds, terpenoids, alcohols, aldehydes and other important bioactive 
compounds [8]. Essential oils often have antibacterial, antifungal, insecticidal, antioxidant and anti-inflammatory properties [5,9-11] and have therefore been used in the preservation of post-harvest crops and food [12]. Owing to the antimicrobial properties of essential oils from various plants, they have potential applications in the preservation of raw and processed food, as well as in pharmaceutical, natural and alternative medicine [7].

Currently, many essential oils from various plants and their parts have been used in the pharmaceutical, perfume, cosmetic and food industries [13-15]. However, there are few reports on essential oils from marine algae and their potential antimicrobial applications, despite the ease and large-scale cultivation of marine algae. Nevertheless, marine algae have been shown to have pharmaceutical properties; therefore, there is growing interest regarding the use of the active compounds from marine algae in various applications of prospective pharmaceuticals. Enteromorpha linza (L.) J. Ag. is an edible, green, broad paddle-shaped seaweed commonly seen in Asian, North European and Mediterranean coastal areas [16]. The seaweed is rich in various bioactive compounds, and few of its medicinal potentials have been reported $[17,18]$. Therefore, in this study, we evaluated the antibacterial potential of essential oil from Enteromorpha linza L. (AEO) against foodborne pathogens, as well as its mechanism of action.

\section{Results}

\subsection{Antibacterial Activity of AEO}

The antibacterial potential of AEO against two different foodborne bacterial pathogens is presented in Table 1. The results revealed that AEO exerted moderate bactericidal activity against S. aureus and B. cereus with zones of inhibition ranging between 12.3 and $13.3 \mathrm{~mm}$ (Table 1). Rifampicin, a standard antibiotic, showed higher bactericidal activity against all four strains, whereas the negative control dimethyl sulfoxide (DMSO) showed no inhibitory activity. The minimum inhibitory concentration (MIC) and minimum bactericidal concentration (MBC) value of AEO against all tested bacteria ranged from 12.5 to $25 \mathrm{mg} / \mathrm{mL}$ (Table 2).

Table 1. Evaluation of antibacterial activity of Enteromorpha linza essential oil against selected foodborne bacteria.

\begin{tabular}{ccc}
\hline \multirow{2}{*}{ Bacterial Pathogens } & \multicolumn{2}{c}{ Diameter of Inhibition Zone (mm) } \\
\cline { 2 - 3 } & Essential Oil ** & Standard *** \\
\hline Bacillus cereus ATCC 10876 & $12.7 \pm 1.5^{\mathrm{a}, *}$ & $24.0 \pm 2.8^{\mathrm{b}}$ \\
B. cereus ATCC 13061 & $12.3 \pm 0.6^{\mathrm{a}}$ & $27.7 \pm 0.6^{\mathrm{a}}$ \\
Staphylococcus aureus ATCC 49444 & $13.3 \pm 1.5^{\mathrm{a}}$ & $24.5 \pm 0.7^{\mathrm{b}}$ \\
(reclassified as S. pseudintermedius) [19] & $12.7 \pm 0.6^{\mathrm{a}}$ & $27.7 \pm 0.6^{\mathrm{a}}$ \\
S. aureus ATCC 12600 &
\end{tabular}

* Data are expressed as the means \pm standard deviation. Values in the same column with different superscripts are significantly different at $p<0.05 ;{ }^{* *}$ Essential oil at $25 \mathrm{mg} / \mathrm{disc} ;{ }^{* * *}$ Standard was rifampicin at $20 \mu \mathrm{g} / \mathrm{disc}$.

Table 2. Determination of MIC and MBC values of Enteromorpha linza essential oil against selected foodborne bacteria.

\begin{tabular}{ccc}
\hline Bacterial Pathogens & MIC * & MBC * $^{*}$ \\
\hline B. cereus ATCC 10876 & 25 & 25 \\
B. cereus ATCC 13061 & 12.5 & 12.5 \\
S. aureus ATCC 49444 & 12.5 & 12.5 \\
(reclassified as S. pseudintermedius) [19] & 12.5 & 25 \\
\hline S. aureus ATCC 12600 &
\end{tabular}

${ }^{*}$ Data are expressed in $\mathrm{mg} / \mathrm{mL}$. 


\subsection{Viability of Bacterial Cells}

One foodborne bacterial strain (B. cereus ATCC 13061) was selected for a further in-depth study of the antibacterial mode of action of AEO against the tested foodborne pathogens. The effects of AEO on cell viability are presented in Figure 1. AEO at the MIC concentration did not show any significant reduction in viable cell count of the bacteria until $4 \mathrm{~h}$ of incubation; however, it controlled the growth of viable cells completely after $6 \mathrm{~h}$ of incubation (Figure 1).

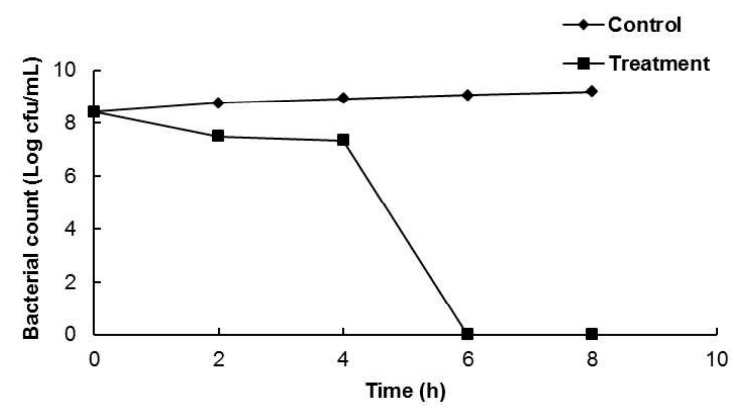

Figure 1. Effect of Enteromorpha linza essential oil (AEO) at MIC concentration on the viability of Bacillus cereus ATCC 13061. Data are expressed as the mean \pm SD.

\subsection{Effect on Release of $260 \mathrm{~nm}$ Absorbing Materials}

The release of cellular materials such as nucleic acids, proteins and metabolites from $B$. cereus ATCC 13061 treated with AEO is presented in Figure 2. When B. cereus ATCC 13061 was treated with the MIC concentration of AEO, there was a continual increase in the concentration of $260 \mathrm{~nm}$ absorbing materials over 120 min of incubation (Figure 2). The control treated with DMSO did not show an increase in the concentration of $260 \mathrm{~nm}$ absorbing materials after $60 \mathrm{~min}$ of incubation.

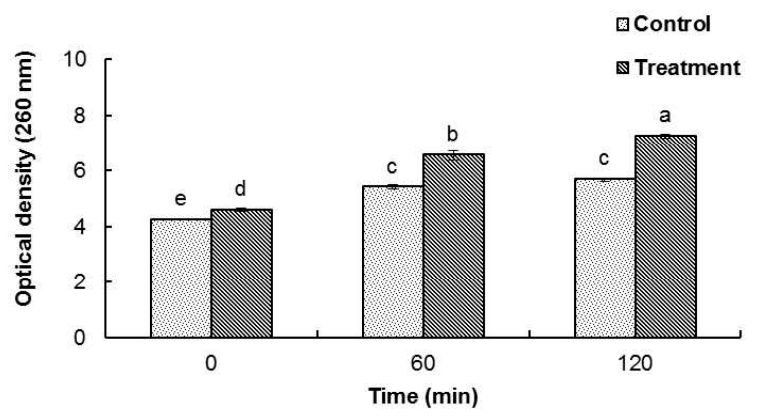

Figure 2. Effect of Enteromorpha linza essential oil (AEO) at MIC concentration on the release of $260 \mathrm{~nm}$ absorbing material of Bacillus cereus ATCC 13061. Data are expressed as the mean \pm SD. Values with different superscript letters are significantly different at $p<0.05$.

\subsection{Permeability of Cell Membrane and Leakage of Potassium Ion}

The permeability of the cell membrane was measured based on the electrical conductivity and leakage of potassium ions from B. cereus ATCC 13061 treated with DMSO or AEO. The control treated with DMSO showed no change in relative conductivity over $8 \mathrm{~h}$ of incubation; however, $B$. cereus ATCC 13061 treated with AEO at the MIC concentration showed a steady increase in electrical conductivity (Figure 3). Furthermore, after $6 \mathrm{~h}$ of incubation, there was a sharp increase in electrical conductivity (Figure 3), which corresponded to the complete loss of viability of B. cereus ATCC 13061 treated with the MIC concentration of AEO after $6 \mathrm{~h}$ of incubation as shown in Figure 1.

Another parameter for permeability impairedness can be the leakage of $\mathrm{K}^{+}$ions from cells. When B. cereus ATCC 13061 was treated with AEO at the MIC concentration, the leakage of potassium 
ions was observed (Figure 4). As shown in Figure 4, B. cereus ATCC 13061 treated with AEO showed continual leakage of $\mathrm{K}^{+}$ions, especially with a sharp increase after $6 \mathrm{~h}$ of incubation (Figure 4 ), which also corresponded with a sharp increase in the cell membrane permeability after $6 \mathrm{~h}$ of incubation as shown in Figure 3.

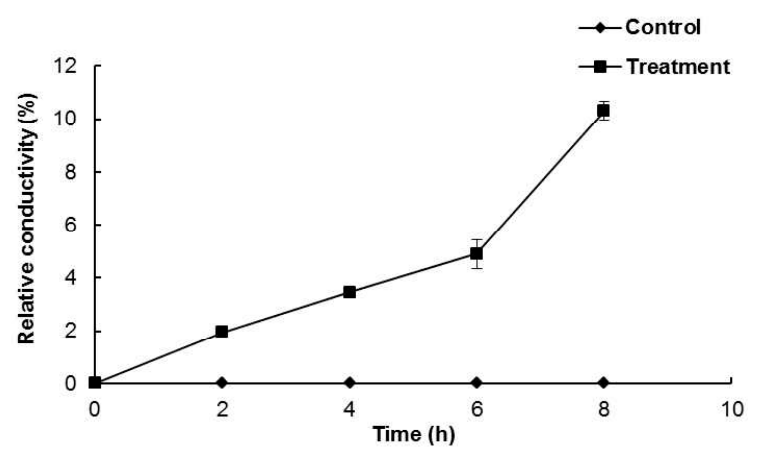

Figure 3. Effect of Enteromorpha linza essential oil (AEO) at MIC concentration on permeability of the cell membrane of Bacillus cereus ATCC 13061. Data are expressed as the mean \pm SD.

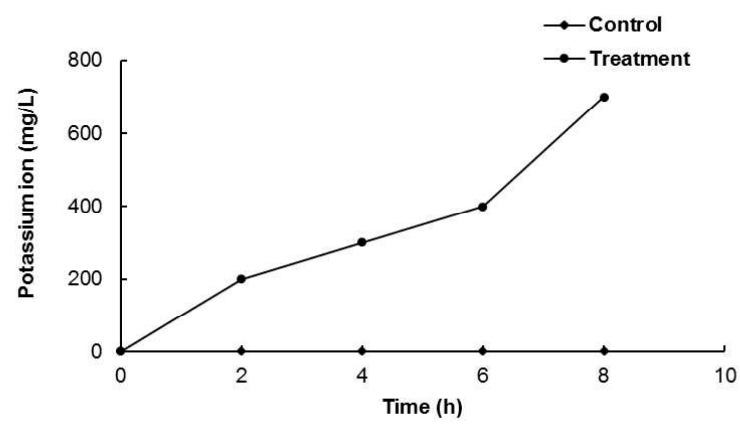

Figure 4. Effect of Enteromorpha linza essential oil (AEO) at MIC concentration on leakage of potassium ions from Bacillus cereus ATCC 13061.

\subsection{Loss of Salt Tolerance Capacity}

The salt tolerance potential of B. cereus ATCC 13061 treated with AEO at the MIC concentration is shown in Figure 5. When the bacteria pretreated with AEO or DMSO were inoculated on nutrient agar media supplemented with different concentrations of $\mathrm{NaCl}(0 \%, 2.5 \%, 5 \%$ and $10 \%)$, a significant decrease in the number of colony-forming units at each concentration was observed in the AEO-pretreated bacteria relative to those pretreated with DMSO (Figure 5). Neither the control nor the treated sample showed any growth of bacteria in the NA plates supplemented with $10 \% \mathrm{NaCl}$.

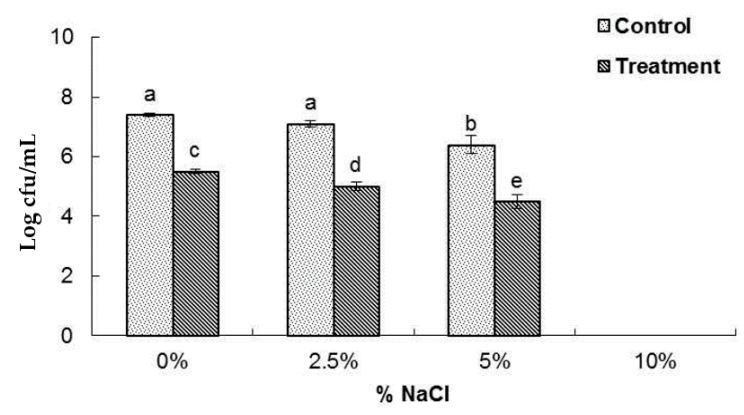

Figure 5. Effect of Enteromorpha linza essential oil (AEO) at MIC concentration on the reduction of salt tolerance of Bacillus cereus ATCC 13061. Data are expressed as the mean \pm SD. Values with different superscript letters are significantly different at $p<0.05$. 


\subsection{SEM Analysis}

The effect of AEO on the cellular structure of the bacteria was further visualized by SEM analysis (Figure 6). The cells of B. cereus ATCC 13061 treated with AEO at the MIC concentration showed abnormal morphology accompanied with longer and swollen shapes relative to the control with a regular and smooth surface (Figure 6).

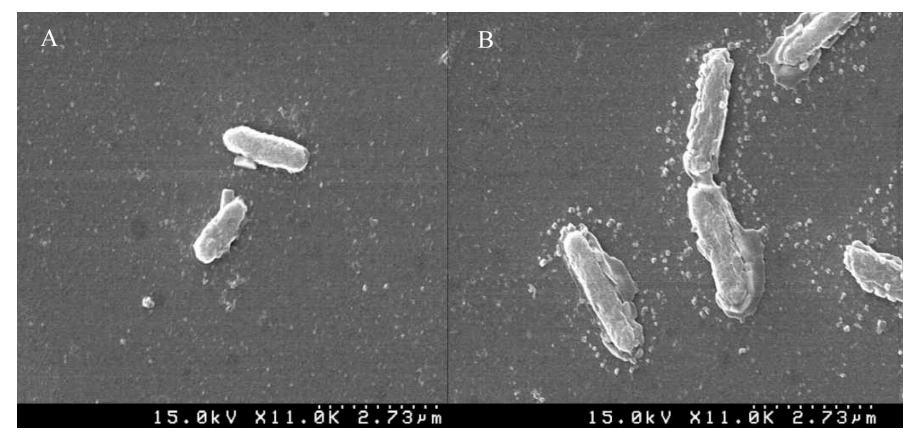

Figure 6. Scanning electron microscopy of Bacillus cereus ATCC 13061. (A): untreated B. cereus; (B): B. cereus treated with the essential oil from Enteromorpha linza.

\section{Discussion}

Decrease in the nutritional quality of food, food poisoning, food spoilage and other food-related diseases are primarily caused by a group of foodborne pathogens $[9,11,20]$. Synthetic chemicals and physical methods are being used by various food industries to prevent contamination and preserve food from these harmful pathogens [21]. However, many of the techniques and chemicals applied are found to be ineffective or result in different health issues and side effects, eventually affecting the safety of food as well as that of the consumers. Increased awareness among the consumers regarding the use of natural products in food preservation has forced the food industries to search for alternative natural preservatives with potential for use in food processing and preservation while increasing the shelf-life of food items.

Seaweeds are rich in protein, vitamins and minerals and are extensively consumed by people of many countries, especially in South Korea, Japan and China, in both fresh and dry form [22]. Many seaweeds have been found to have antioxidant, antimicrobial, anticoagulant, and anti-ulcer activities [23,24]. However, extraction of essential oils from these edible seaweeds and their potential bactericidal activity against various foodborne pathogens has not been intensively investigated. Therefore, through this research, the antibacterial potentials of essential oil from the fresh edible seaweed E. linza L. against two dominant foodborne bacteria and their modes of action were investigated.

AEO displayed potent antibacterial activity against both B. cereus (ATCC 10876 and ATCC 13061) and S. aureus (ATCC 12600), S. aureus ATCC 49444 (reclassified as S. pseudintermedius) [19] (Table 1). Previously, the antimicrobial potentials of different extracts and essential oil from various seaweeds against different types of microorganisms were reported $[17,19,22,25,26]$, and our research also verified the effectiveness of the essential oil from E. linza on controlling two devastating foodborne pathogens. The antibacterial potential of $\mathrm{AEO}$ against $B$. cereus and $S$. aureus might be due to the presence of a number of active compounds such as hexadecanoic acid, nonadecadiene, tetradecanoic acid, tridecanol and azetidine, etc., in the AEO, as evident from the GC-MS analysis [27]. A possible mechanism for the antibacterial effects of AEO might be the hydrophobic properties of essential oils that easily penetrate into the bacterial cells due to the structure of the cell wall of Gram-positive bacteria eventually causing cellular death [28].

The mode of action of AEO against the investigated foodborne bacteria was revealed by several assays, including cell viability, leakage of $260 \mathrm{~nm}$ absorbing materials, cell membrane leakage, loss of salt tolerance and direct observation of cell morphology by SEM using B. cereus ATCC 13061 as the 
model system. The bacterial cells treated with AEO at the MIC concentration did not have any viable cells after $6 \mathrm{~h}$ of co-incubation (Figure 1), which might have been due to the easy penetration of AEO into the bacterial cell resulting in complete lysis and cellular death [28].

A significant increase in the optical density at $260 \mathrm{~nm}$ was observed in the bacterial solution treated with AEO (Figure 2), indicating a more active release of intercellular materials such as nucleic acids to the outer solution by cellular leakage. A previous study revealed that essential oils caused hole-like deformities in the cell surface, resulting in cellular leakage $[9,29]$. The bacterial cytoplasmic membrane provides a selective barrier to small ions such as $\mathrm{K}^{+}, \mathrm{Ca}^{2+}, \mathrm{Na}^{+}$, preventing entry and exit from the cells. This control of permeability by the cellular membrane is the key regulatory factor for various cellular functions, including cell metabolism maintenance, solute transport, energy transduction processes, etc. [30,31]. The permeability of the cytoplasmic membrane of $B$. cereus ATCC 13061 was significantly impaired by the addition of AEO into the culture of $B$. cereus as indicated by the significant increase in the relative electrical conductivity and the concentration of $\mathrm{K}^{+}$ions in the bacterial solution (Figures 3 and 4). Hydrophobicity is an important property of essential oils that leads to the accumulation of oils inside bacterial cell membranes, resulting in cellular lysis by disturbance of their structure and increased cellular leakage [32-34]. The loss of the osmoregulation potential of bacterial cells to salts by the addition of AEO was observed (Figure 5). This loss of salt tolerance is additional strong evidence confirming damage to the membrane of bacterial cells due to the accumulation of essential oil in them [35].

B. cereus ATCC 13061 treated with AEO at the concentration of MIC experienced severe morphological changes (Figure 6), which again confirmed the mechanism of antibacterial action of AEO. Clear morphological alterations in the cell wall of bacteria treated with essential oils have been reported in many studies [36-40]. These changes in the physical and morphological characteristics of the bacterial cells explain the effect of AEO on their integrity and the permeability of the bacterial cell eventually causing cellular lysis and death.

\section{Materials and Methods}

\subsection{Chemicals and Instruments}

All chemicals, including rifampicin, were purchased from Merck (Rahway, NJ, USA) or Sigma-Aldrich (St. Louis, MO, USA). A spectrophotometer (ASP 3700, ACTGene Inc., Piscataway, NJ, USA), conductivity meter (Con 6, LaMotte, Chestertown, MD, USA) and scanning electron microscope (S-4110, Hitachi, Tokyo, Japan) were used for spectrophotometric analysis, conductivity measurement and microscopic observation, respectively.

\subsection{Extraction of Essential Oil from E. linza}

Fresh green seaweed of E. linza was purchased from a local market in Gyeongsan, Gyeongbuk, Korea. A total of $500 \mathrm{~g}$ of seaweed was washed with distilled water and then put in a $10 \mathrm{~L}$ glass container. Next, $5 \mathrm{~L}$ of distilled water was added and the sample was subjected to hydro-distillation using a micro-wave assisted extraction machine manufactured by KMD Engineering (Paju, Korea) for $4 \mathrm{~h}$. The operation conditions were an oven power capacity of $40 \mathrm{~W}$ and frequency of $15 \mathrm{gkH}$. The collected distillate was mixed with dichloromethane in a separating funnel, shaken vigorously and kept until the samples settled. The lower layer of the separating funnel was collected and concentrated using a rotary evaporator (N-1110, EYELA, Tokyo Rikakikai Co., Ltd., Tokyo, Japan) at $40^{\circ} \mathrm{C}$. The algae essential oil (AEO) was then dried over anhydrous sodium sulfate and kept in a tightly closed vial at $4{ }^{\circ} \mathrm{C}$ until use. The AEO was obtained as a light yellow transparent liquid with a $0.32 \%$ yield.

\subsection{Foodborne Bacterial Pathogens}

Four different foodborne bacterial pathogens from two species were used in the present study. These strains included Bacillus cereus (ATCC 10876 and ATCC 13061) and Staphylococcus aureus 
(ATCC 12600 and ATCC 49444). The bacterial pathogens were grown on nutrient broth media (Difco; Becton, Dickinson and Company, Sparks Glencoe, MD, USA).

\subsection{Determination of Antibacterial Potential of AEO}

Prior to use, AEO was diluted to $50 \%(v / v)$ in $5 \%$ dimethylsulphoxide (DMSO) and then sterilized through a $0.22 \mu \mathrm{m}$ nylon syringe filter. The antibacterial potential of AEO was evaluated against the four foodborne pathogens using the standard disc diffusion method [1]. A total $100 \mu \mathrm{L}$ of suspension containing $10^{7} \mathrm{cfu} / \mathrm{mL}$ of the four foodborne bacterial pathogens was uniformly spread on separate nutrient agar (NA) plates. Paper discs (6 mm, Advantec, Toyo Roshi Kaisha Ltd., Tokyo, Japan) with $25 \mathrm{mg} /$ disc of AEO were placed on the inoculated agar. Rifampicin $(20 \mu \mathrm{g} / \mathrm{disc})$ was used as a positive control and $5 \%$ DMSO as a negative control. The diameters of zones of inhibition were measured after $24 \mathrm{~h}$ of incubation at $37^{\circ} \mathrm{C}$.

The minimum inhibitory concentration (MIC) and minimum bactericidal concentration (MBC) were determined by the two-fold dilution method, with minor modifications as described by Kubo et al. [41]. The lowest concentration of AEO not showing any visible growth of test organisms was determined as the MIC value and the concentration showing complete absence of growth of bacterial colonies on the agar surface was defined as the $\mathrm{MBC}$ value $(\mathrm{mg} / \mathrm{mL})$.

\subsection{Viability of Bacterial Cell}

The antibacterial effect of AEO on the viability of the bacterial pathogens with respect to incubation time was evaluated by the time kill assay [42]. Only one foodborne bacterium, B. cereus (ATCC 13061), was selected for the assay. Bacterial culture with AEO at MIC concentration and bacterial cultures with 5\% DMSO were used as the treatment and control, respectively. One $\mathrm{mL}$ of the bacteria culture $\left(10^{7} \mathrm{cfu} / \mathrm{mL}\right)$ was added to the assay and total volume was $10 \mathrm{~mL}$. The cultures were incubated at $37^{\circ} \mathrm{C}$ for $8 \mathrm{~h}$, during which time bacterial samples were taken from the incubator at every $2 \mathrm{~h}$, serially diluted in phosphate buffer saline, spread on the surface of nutrient agar plates and incubated at $37^{\circ} \mathrm{C}$ for $24 \mathrm{~h}$. Subsequently, the colonies were counted in terms of colony-forming units (cfu) per mL of sample.

\subsection{Integrity of the Cell Membrane}

The integrity of the cell membrane of B. cereus (ATCC 13061) was determined by the degree of cellular materials, especially DNA and RNA, in the supernatant [32]. AEO at the MIC concentration was added to $2 \mathrm{~mL}$ of the bacterial inoculum $\left(10^{7} \mathrm{cfu} / \mathrm{mL}\right)$ in sterilized peptone water $(0.1 \mathrm{~g} / 100 \mathrm{~mL})$ and then incubated at $37^{\circ} \mathrm{C}$. Bacterial samples were collected after 0,60 and $120 \mathrm{~min}$ of incubation and centrifuged at $1372 \mathrm{~g}$, after which the UV absorbance of the supernatant was measured at $260 \mathrm{~nm}$ using a spectrophotometer. Corrections for treated cultures were made by taking AEO without bacteria in sterilized peptone water. The untreated bacterial cultures were corrected with sterile peptone water.

\subsection{Permeability of the Cell Membrane}

The effect of AEO on bacterial cell membrane permeability in terms of relative electrical conductivity was determined according to the standard method described by Kong et al. [43]. Prior to the experiment, B. cereus (ATCC 13061) was subcultured in nutrient broth media and incubated at $37^{\circ} \mathrm{C}$ for $10 \mathrm{~h}$. Following incubation, the bacterial pathogen were centrifuged at $2800 \mathrm{~g}$ for $10 \mathrm{~min}$, and then washed with $5 \%$ glucose until its electrical conductivity was near to that of $5 \%$ glucose as measured in a conductivity meter (Con 6; LaMotte Company, Chestertown, MD, USA). AEO at the MIC concentration was added to $5 \%$ glucose and its electrical conductivity was determined $\left(\mathrm{L}_{1}\right)$. MIC concentration of AEO was added to the isotonic bacterial solution, mixed completely and incubated at $37^{\circ} \mathrm{C}$ for $8 \mathrm{~h}$, during which time the electrical conductivity of the AEO-bacterial mixture was measured every $2 \mathrm{~h}\left(\mathrm{~L}_{2}\right)$. The control was the killed bacteria in $5 \%$ glucose by being treated in 
boiling water for $5 \mathrm{~min}$. The electrical conductivity of the control was marked as $\mathrm{L}_{0}$. The permeability of the bacteria membrane in terms of its relative electrical conductivity was calculated as follows:

$$
\text { Relative conductivity }(\%)=100 \times\left[\left(\mathrm{L}_{2}-\mathrm{L}_{1}\right) / \mathrm{L}_{0}\right]
$$

\subsection{Leakage of Potassium Ion}

The leakage of potassium $\left(\mathrm{K}^{+}\right)$ion into the bacterial suspension was determined as described by Paul et al. [44]. The leakage of free $\mathrm{K}^{+}$ion in the bacterial suspension of B. cereus (ATCC 13061) was detected after exposing the bacteria $\left(10^{7} \mathrm{cfu} / \mathrm{mL}\right)$ to the MIC concentration of AEO in sterile peptone water $(0.1 \mathrm{~g} / 100 \mathrm{~mL})$ and incubating the samples at $37^{\circ} \mathrm{C}$ for $8 \mathrm{~h}$, during which time the extracellular potassium concentration was measured every $2 \mathrm{~h}$ using a Kalium/Potassium kit (Quantofix, Macherey-Nagel GmbH \& Co. KG, Duren, Germany). A culture flask without AEO was used as a control. All data were reported as the amount of free $\mathrm{K}^{+}$ion $(\mathrm{mg} / \mathrm{L})$ in the bacterial suspension at each time interval.

\subsection{Loss of Salt Tolerance}

The salt tolerance effect of B. cereus (ATCC 13061) treated with the MIC concentration of AEO was evaluated on nutrient agar plates supplemented with different concentrations of $\mathrm{NaCl}$ [35]. Prior to use, B. cereus was cultured fresh and incubated at $37^{\circ} \mathrm{C}$ for overnight. After incubation, the overnight culture of $B$. cereus were treated with AEO and further incubated for $60 \mathrm{~min}$ at $37^{\circ} \mathrm{C}$. Then the samples were serially diluted and inoculated on NA plates supplemented with different concentrations of $\mathrm{NaCl}$ $(0 \%, 2.5 \%, 5.0 \%$ and $10.0 \%)$. Bacterial culture without AEO was used as the control for each NA-NaCl plate. After incubation, both the control and treatment plates were compared, and the results were expressed in terms of $\log 10 \mathrm{cfu} / \mathrm{mL}$. The experiment was repeated three times.

\subsection{Scanning Electron Microscopy (SEM) Analysis}

The effects of the essential oil on the morphology of B. cereus (ATCC 13061) were determined by SEM [30]. Overnight cultures of both control and treated samples were centrifuged at $1000 \times g$ for $10 \mathrm{~min}$, after which the pellet was washed slowly with $50 \mathrm{mM}$ phosphate buffer solution ( $\mathrm{pH} 7.2)$, mounted over glass slides and fixed with $100 \mathrm{~mL}$ glutaraldehyde $(2.5 \%)$. The specimen was then dehydrated using different concentrations of ethanol (50\%-100\%). Finally, ethanol was replaced by $t$-butanol and incubated at room temperature for $2 \mathrm{~h}$. Finally, the specimen was sputter-coated with platinum in an ion coater for $120 \mathrm{~s}$ and observed by SEM (S-4100; Hitachi).

\subsection{Statistical Analysis}

The results were expressed as the mean \pm standard deviation (SD) and the statistical analysis were done using Statistical Analysis Software (SAS) version 9.4 (SAS Inc., Cary, NC, USA). One way ANOVA and Duncan's multiple range tests were done and the results were considered significant at probability $p<0.05$.

\section{Conclusions}

The results of the present study indicate that AEO from the edible seaweed E. linza can be a potential alternative antibacterial agent that can be used as an additive in food to act against foodborne pathogens. Study on the mechanism of action of AEO indicated that it influences the permeability of the cellular membrane by binding to the cell surface and then penetrating the bacterial cell membrane, thereby resulting in cellular lysis and cell death.

Acknowledgments: This work was carried out with the support of "Cooperative Research Program for Agriculture Science \& Technology Development (Project No. PJ010934042016)” Rural Development Administration, Korea. 
Author Contributions: J.K.P. has contributed in performing experiment and writing manuscript. K.H.B. contributed in planning and designing the study and analysis of data. Both the authors participated in drafting the manuscript; they have read and approved the final manuscript.

Conflicts of Interest: The authors declare no conflict of interest.

\section{References}

1. Diao, W.R.; Hu, Q.P.; Feng, S.S.; Li, W.Q.; Xu, J.G. Chemical composition and antibacterial activity of the essential oil from green huajiao (Zanthoxylum schinifolium) against selected foodborne pathogens. J. Agric. Food Chem. 2013, 61, 6044-6049. [CrossRef] [PubMed]

2. Shan, B.; Cai, Y.Z.; Brooks, J.D.; Corke, H. Antibacterial properties and major bioactive components of cinnamon stick (Cinnamomum burmannii): Activity against foodborne pathogenic bacteria. J. Agric. Food Chem. 2007, 55, 5484-5490. [CrossRef] [PubMed]

3. Sokmen, A.; Gulluce, M.; Akpulat, H.A.; Daferera, D.; Tepe, B.; Polissiou, M.; Sokmen, M.; Sahin, F. The in vitro antimicrobial and antioxidant activities of the essential oils and methanol extracts of endemic Thymus spathulifolius. Food Control 2004, 15, 627-634. [CrossRef]

4. Wu, V.C.H.; Qiu, X.; Delos-Reyes, B.G.; Lin, C.S.; Pan, Y. Application of cranberry concentrate (Vaccinium macrocarpon) to control Escherichia coli O157:H7 in ground beef and its antimicrobial mechanism related to the down regulated slp, hdeA and cfa. Food Microbiol. 2009, 26, 32-38. [CrossRef] [PubMed]

5. Klein, G.; Ruben, C.; Upmann, M. Antimicrobial activity of essential oil components against potential food spoilage microorganisms. Curr. Microbiol. 2013, 67, 200-208. [CrossRef] [PubMed]

6. Jones, F.A. Herbs-Useful plants. Their role in history and today. Eur. J. Gastroenterol. Hepatol. 1996, 8, 1227-1231. [CrossRef] [PubMed]

7. Hammer, K.A.; Carson, C.F.; Riley, T.V. Antimicrobial activity of essential oils and other plant extracts. J. Appl. Microbiol. 1999, 86, 985-990. [CrossRef] [PubMed]

8. LuzIda, S.; GomesNeto, N.J.; Tavares, A.G.; Nunes, P.C.; Magnani, M.; de Souza, E.L. Evidence for lack of acquisition of tolerance in Salmonella enterica serovar Typhimurium ATCC 14028 after exposure to subinhibitory amounts of Origanum vulgare L. essential oil and carvacrol. Appl. Environ. Microbiol. 2012, 78, 5021-5024.

9. Diao, W.R.; Hu, Q.P.; Zhang, H.; Xu, J.G. Chemical composition, antibacterial activity and mechanism of action of essential oil from seeds of fennel (Foeniculum vulgare Mill). Food Control 2014, 35, 109-116. [CrossRef]

10. Cakir, A.; Kordali, S.; Kilic, H.; Kaya, E. Antifungal properties of essential oil and crude extracts of Hypericum linarioides Bosse. Biochem. Syst. Ecol. 2005, 33, 245-256. [CrossRef]

11. Bajpai, V.K.; Sharma, A.; Baek, K.H. Antibacterial mechanism of action of Texus cuspidata stem essential oil against selected foodborne pathogens. J. Food Saf. 2013, 33, 348-359. [CrossRef]

12. Mishra, A.K.; Dubey, N.K. Evaluation of some essential oils for their toxicity against fungi causing deterioration of stored food commodities. Appl. Environ. Microbiol. 1994, 60, 1101-1105. [PubMed]

13. Hyldgaard, M.; Mygind, T.; Meyer, R.L. Essential oils in food preservation: Mode of action, synergies, and interactions with food matrix components. Front. Microbiol. 2012, 3, 12. [CrossRef] [PubMed]

14. Herman, A.; Herman, A.P.; Domagalska, B.W.; Młynarczyk, A. Essential oils and herbal extracts as antimicrobial agents in cosmetic emulsion. Indian J. Microbiol. 2013, 53, 232-237. [CrossRef] [PubMed]

15. Tongnuanchan, P.; Benjakul, S. Essential oils: Extraction, bioactivities, and their uses for food preservation. J. Food Sci. 2014, 79, R1231-R1249. [CrossRef] [PubMed]

16. Say, P.J.; Burrows, I.G.; Whitton, B.A. Enteromorpha as a Monitor of Heavy Metals in Estuarine and Coastal Intertidal Waters: A Method for the Sampling, Treatment and Analysis of the Seaweed Enteromorpha to Monitor Heavy Metals in Estuaries and Coastal Waters; Northern Environmental Consultants Ltd.: Durham, UK, 1986; pp. 8-9.

17. Sukatar, A.; Karabay-Yavasoglu, N.U.; Ozdemir, G.; Horzum, Z. Antimicrobial activity of volatile component and various extracts of Enteromorpha linza (Linnaeus) J. Agardh from the coast of Izmir, Turkey. Anal. Microbiol. 2006, 56, 275-279.

18. Park, N.H.; Choi, J.S.; Hwang, S.Y.; Kim, Y.C.; Hong, Y.K.; Cho, K.K.; Choi, I.S. Antimicrobial activities of stearidonic and gamma-linolenic acids from the green seaweed Enteromorpha linza against several oral pathogenic bacteria. Bot. Stud. 2013, 54, 39. [CrossRef] 
19. Ramsey, K.J.; Carter, E.C.; McKee, M.L.; Beck, B.J. Reclassification of the Listeria-CAMP test strain ATCC 49444 Staphylococcus aureus as Staphylococcus pseudintermedius. J. Food Prot. 2010, 8, 1408-1590.

20. Turgis, M.; Dang-Vu, K.; Dupont, C.; Lacroix, M. Combined antimicrobial effect of essential oils and bacteriocins against foodborne pathogens and food spoilage bacteria. Food Res. Int. 2012, 48, 696-702. [CrossRef]

21. Li, Y.Y.; Yi, Z.Y. Present situation and development of food antistaling agent and preservatives. J. Beijing Inst. Petrochem. Technol. 2003, 11, 18-23.

22. Demirel, Z.; Yilmaz-Koz, F.F.; Karabay-Yavasoglu, N.U.; Ozdemir, G.; Sukatar, A. Antimicrobial and antioxidant activities of solvent extracts and the essential oil composition of Laurencia obtusa and Laurencia obtusa var. pyramidata. Rom. Biotechnol. Lett. 2011, 16, 5927-5936.

23. Kandhasamy, M.; Arunachalam, K.D. Evaluation of in vitro antibacterial property of seaweeds of southeast coast of India. Afr. J. Biotechnol. 2008, 7, 1958-1961.

24. Rajasulochana, P.; Hamotharan, R.; Krishnamoorthy, P.; Murugesan, S. Antibacterial activity of the extracts of marine red and brown algae. J. Am. Sci. 2009, 5, 20-25.

25. Koz, F.F.Y.; Yavasoglu, N.U.K.; Demirel, Z.; Sukatar, A.; Ozdemir, G. Antioxidant and antimicrobial activities of Codium fragile (Suringar) Hariot (Chlorophyta) essential oil and extracts. Asian J. Chem. 2009, 21, 1197-1209.

26. Gressler, V.; Stein, E.M.; Dorr, F.; Fujii, M.T.; Colepicolo, P.; Pinto, E. Sesquiterpenes from the essential oil of Laurencia dendroidea (Ceramiales, Rhodophyta): Isolation, biological activities and distribution among seaweeds. Braz. J. Pharmacogn. 2011, 21, 248-254. [CrossRef]

27. Patra, J.K.; Kim, S.H.; Baek, K.H. Antioxidant and free radical-scavenging potential of essential oil from Enteromorpha linza L. prepared by microwave-assisted hydrodistillation. J. Food Biochem. 2015, 39, 80-90.

28. Sikkema, J.; De-Bont, J.A.M.; Poolman, B. Interactions of cyclic hydrocarbons with biological membranes. J. Biol. Chem. 1994, 269, 8022-8028. [PubMed]

29. Zhu, S.Y.; Yang, Y.; Yu, H.D.; Ying, Y.; Zou, G.L. Chemical composition and antimicrobial activity of the essential oils of Chrysanthemum indicum. J. Ethnopharmacol. 2005, 96, 151-158.

30. Bajpai, V.K.; Al-Reza, S.M.; Choi, U.K.; Lee, J.H.; Kang, S.C. Chemical composition, antibacterial and antioxidant activities of leaf essential oil and extracts of Metaseqoia glyptostroboides Miki ex Hu. Food Chem. Toxicol. 2009, 47, 1876-1883. [CrossRef] [PubMed]

31. Cox, S.D.; Gustafson, J.E.; Mann, C.M.; Markhan, J.L.; Liew, Y.C.; Hartlnd, R.P. Tea tree oil causes K ${ }^{+}$leakage and inhibits respiration in Escherichia coli. Lett. Appl. Microbiol. 1998, 26, 355-358. [CrossRef] [PubMed]

32. Carson, C.F.; Mee, B.J.; Riley, T.V. Mechanism of action of Melaleuca alternifolia (tea tree) oil on Staphylococcus aureus determined by time-kill, lysis, leakage, and salt tolerance assays and electron microscopy. Antimicrob. Agents Chemother. 2002, 46, 1914-1920. [CrossRef] [PubMed]

33. Lambert, R.J.W.; Skandamis, P.N.; Coote, P.; Nychas, G.J.E. A study of the minimum inhibitory concentration and mode of action of oregano essential oil, thymol and carvacrol. J. Appl. Microbiol. 2001, 91, 453-462. [CrossRef] [PubMed]

34. Moreira, M.R.; Ponce, A.G.; Del-Valle, C.E.; Roura, S.I. Inhibitory parameters of essential oils to reduce a foodborne pathogen. LWT Food Sci. Technol. 2005, 38, 565-570. [CrossRef]

35. Miksusanti, M.; Jenie, B.S.L.; Priosoeryanto, B.; Syarief, R.; Rekso, G. Mode of action Temu kunci (Kaempferia pandurata) essential oil on E. coli K1.1 cell determined by leakage of material cell and salt tolerance assays. Hayati J. Biosci. 2008, 15, 56-60.

36. Gustafson, J.E.; Liew, Y.C.; Markham, J.; Bell, H.C.; Wyllie, S.G.; Warmington, J.R. Effects of tea tree oil on Escherichia coli. Lett. Appl. Microbiol. 1998, 26, 194-198. [CrossRef] [PubMed]

37. Burt, S.A.; Reinders, R.D. Antibacterial activity of selected plant essential oils against Escherichia coli O157:H7. Lett. Appl. Microbiol. 2003, 36, 162-167. [CrossRef] [PubMed]

38. Becerril, R.; Gomez-Lus, R.; Goni, P.; Lopez, P.; Nerin, C. Combination of analytical and microbiological techniques to study the antimicrobial activity of a new active food packaging containing cinnamon or oregano against E. coli and S. aureus. Anal. Bioanal. Chem. 2007, 388, 1003-1011. [CrossRef] [PubMed]

39. Di-Pasqua, R.; Betts, G.; Hoskins, N.; Edwards, M.; Ercolini, D.; Mauriello, G. Membrane toxicity of antimicrobial compounds from essential oils. J. Agric. Food Chem. 2007, 55, 4863-4870. [CrossRef] [PubMed]

40. Bouhdid, S.; Abrini, J.; Zhiri, A.; Espuny, M.J.; Manresa, A. Investigation of functional and morphological changes in Pseudomonas aeruginosa and Staphylococcus aureus cells induced by Origanum compactum essential oil. J. Appl. Microbiol. 2009, 106, 1558-1568. [CrossRef] [PubMed] 
41. Kubo, I.; Fujita, K.; Kubo, A.; Nihei, K.; Ogura, T. Antibacterial activity of coriander volatile compounds against Salmonella choleraesuis. J. Agric. Food Chem. 2004, 52, 3329-3332. [CrossRef] [PubMed]

42. Joray, M.B.; Del-Rollan, M.R.; Ruiz, G.M.; Palacios, S.M.; Carpinella, M.C. Antibacterial activity of extracts from plants of central Argentina-isolation of an active principle from Achyrocline satureioides. Planta Med. 2011, 77, 95-100. [CrossRef] [PubMed]

43. Kong, M.; Chen, X.G.; Liu, C.S.; Meng, X.H.; Yu, L.J. Antibacterial mechanism of chitosan microspheres in a solid dispersing system against E. coli. Colloids Surf. B Biointerfaces 2008, 65, 197-202. [CrossRef] [PubMed]

44. Paul, S.; Dubey, R.C.; Maheswari, D.K.; Kang, S.C. Trachyspermum ammi (L.) fruit essential oil influencing on membrane permeability and surface characteristics in inhibiting food-borne pathogens. Food Control 2011, 22, 725-731.

Sample Availability: Fresh green seaweed, Enteromorpha linza can be available from authors.

(C) 2016 by the authors; licensee MDPI, Basel, Switzerland. This article is an open access article distributed under the terms and conditions of the Creative Commons by Attribution (CC-BY) license (http://creativecommons.org/licenses/by/4.0/). 